HOW TO BE A LEADER 


\section{ANCIENT WISDOM FOR MODERN READERS}

How to Be a Leader: An Ancient Guide to Wise Leadership by Plutarch

How to Think about God: An Ancient Guide for Believers and Nonbelievers by Marcus Tullius Cicero

How to Keep Your Cool: An Ancient Guide to Anger Management by Seneca

How to Think about War: An Ancient Guide to Foreign Policy by Thucydides

How to Be Free: An Ancient Guide to the Stoic Life by Epictetus

How to Be a Friend: An Ancient Guide to True Friendship by Marcus Tullius Cicero

How to Die: An Ancient Guide to the End of Life by Seneca

How to Win an Argument: An Ancient Guide to the Art of Persuasion by Marcus Tullius Cicero

How to Grow Old: Ancient Wisdom for the Second Half of Life by Marcus Tullius Cicero

How to Run a Country: An Ancient Guide for Modern Leaders by Marcus Tullius Cicero

How to Win an Election: An Ancient Guide for Modern Politicians by Quintus Tullius Cicero 


\title{
HOW TO BE A LEADER
}

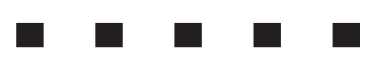

An Ancient Guide to Wise Leadership

\author{
Plutarch
}

Selected, translated, and introduced

by Jeffrey Beneker

PRINCETON UNIVERSITY PRESS

PRINCETON AND OXFORD 
Copyright $\odot 2019$ by Princeton University Press

Published by Princeton University Press

41 William Street, Princeton, New Jersey 08540

6 Oxford Street, Woodstock, Oxfordshire OX20 1TR

press.princeton.edu

All Rights Reserved

Library of Congress Cataloging-in-Publication Data

Names: Plutarch, author. | Beneker, Jeffrey, editor, translator, writer of introduction. | Plutarch. Moralia. Selections. | Plutarch. Moralia. Selections. English.

Title: How to be a leader : an ancient guide to wise leadership / Plutarch ; edited, translated, and introduced by Jeffrey Beneker.

Description: Princeton : Princeton University Press, [2019] | Series: Ancient wisdom for modern readers | In Ancient Greek with parallel English translations on facing pages.

Identifiers: LCCN 2019019549| ISBN 9780691192116 (hardcover)

Subjects: LCSH: Plutarch-Translations into English. | LeadershipEarly works to 1800 .

Classification: LCC PA4368 .A23 2019| DDC 873/.01-dc23

LC record available at https://lccn.loc.gov/2019019549

British Library Cataloging-in-Publication Data is available

Editorial: Rob Tempio and Matt Rohal

Production Editorial: Ali Parrington

Text and Jacket Design: Pamela L. Schnitter

Production: Merli Guerra and Brigid Ackerman

Publicity: Jodi Price, Amy Stewart, and Alyssa Sanford

Jacket/Cover Credit: The Athena Giustiniani, or Giustiniani Minerva.

Parian marble. Antonine Roman copy, 2nd century. Detail. Prisma

Archivo / Alamy Stock Photo

This book has been composed in Stemple Garamond LT,

Futura and Brill

Printed on acid-free paper. $\infty$

Printed in the United States of America

13579108642 


\section{FOR HELEN AND LUIS}


